\title{
The Animation of Serial and Parallel Connections of Resistances ${ }^{\#}$
}

\author{
Nigmet KOKLU * ${ }^{1}$, Dundar YENER ${ }^{2}$, Hamdi Sukur KILIC ${ }^{3}$
}

\author{
Accepted $15^{\text {th }}$ August 2014
}

\begin{abstract}
Technological gadgets increasing everyday allowing newer communication and notations. Of these technological gadgets, animation, simulation, video and multimedia usage in physics teaching provides diverse benefits. Therefore animation and simulation are widely used in education. In such learning environments, students are exploring physics world, thereby they can easily understand and form their basic knowledge. So animation and simulation is used in this study, named "Resistors in Series and in Parallel". Primarily, an animation is composed about resistors in series, then connection of ammeter and voltmeter to series-circuit are showed. For each resistor in experiment, the current and voltage values are told to students through animation. Also the derivation of formulas for current, voltage and resistance calculation in series circuits are told in animation. Afterwards, an animation about resistors in parallel is composed and connection of ammeter to circuit is showed. The current on main branch, then voltage and current values for each resistance are calculated. To comprehend the topic better, arithmetic operations and derivation of formulas are showed in animation.
\end{abstract}

Keywords: Animation, Simulation, Physics Education.

\section{Introduction}

Today students consider knowledge related to the science subjects temporarily used means, consequently try to memorize the subject instead of learning or think that science subjects are too hard or unnecessary to learn. For this reason, the minds of students continuously in uneasiness and fear caused by science learning are considered the most important problem in science education [1].

Researches show that students face the conceptual hardness while learning many science subjects. Meaning that, students cannot materialize some concepts clearly like electricity, mass and weight, gravity, movement, light, matter-substance, temperatureheat in their mind. Tests and interviews with students done before and after giving a lecture about any subject prove that those students have still not changed some of their thoughts and show resistance to the conceptual understanding. According to this, to prevent of incorrect learning and to realize full learning of students, effective procedures and methods of teaching should be developed [2].

Change in educational system, rapid increase in the number of students, increase in knowledge and complicacy of content, teacher inadequacy, increase in importance of individual differences are made the use of computers in education a necessity [3].

In the case of inadequacy of classical equipment and materials used in educational and training environments computers play an important role. Unsafe and dangerous many processes to realize in classical educational environment may easily be realized by using computer created environments. The usage of computers in education and training areas increases the number students reaching the knowledge. Moreover it also provides equality in accessing the knowledge [4].

Utilization of the technological means in educational areas increases efficiency. In many countries educational environments is equipped with technological tools [5].

With the use of computers in educational area, a number of

${ }^{I}$ Technical Sciences Vocational High School, Selçuk University, Campus, 42031, Konya/Turkey

*Corresponding Author: Email: nkoklu@selcuk.edu.tr

\# This paper has been presented at the International Conference on

Advanced Technology\&Sciences (ICAT'14) held in Antalya (Turkey), August 12-15, 2014. educational computer software is being developed. To make the students active learners, to decrease both the financial cost and time cost of the experiments various information and communication technologies exists [6]. Recently, animations get attention in the perspective as the representation of natural and dynamic teaching [7]. Moreover animations and simulations are the applications which ease the comprehension and understanding of science classes.

Animations support education with various activities by the visualizations of education. Employing of the animations helps students comprehend the subject and increases the permanence of the knowledge in the minds of the students. By removing unwillingness for learning increases the effectiveness of the learning. By using animation, students can both read and see and hear at the same time. Thus, utilization of animations increases the permanency of the effective learning [8].

Animation means bringing to life. They are not lifeless and motionless like pictures or caricatures. In animation there is neither continuous activity nor stillness [9]. Animation can be thought of moving pictures and graphics in computer environment.

Animations are an effective way to explain the class subjects in computer environment. Because their educational value is high, their usage in education helps in increasing the efficiency in education. Animations provide better concrete grasp and application of the subjects [10].

Events that are hard to grasp, costly and dangerous to apply in a laboratory environment or takes too much time observe can be shown as invigorated actions in computer environment. This is called simulation [11].

Simulations are simplified demonstration of a real situation or process in computer environment. The difference of the simulations from animations that the possibility of intervention from outside. This means that the experiment can be performed by the individual in computer environment instead of just watching the events. Nonetheless, guidance is still present. Individuals can change numerical values; they may increase or decrease the values. They may observe different results according to changes made.

As in the animations, simulations are also removes time problems, high costs and danger that may appear in real laboratory environment. Learning realized during the application of simulation by the student. Simulation makes the jobs of the 
teacher easier, because they make the transfer of description and observation of hard subjects easier. Students learn by trial and error method. Individual learning is realized [8].

It is thought that animation and simulation class material help students to understand the abstract concepts and present students many learning activities to educate themselves. Animations and simulations can be used aiming to eradicate memorization of subject without learning by the students, to connect the previously learnt information with newly learned one, to active participation of students to learning process in the theory of configurative learning [12].

Bozkurt has reported in his study about using simulations and preparing a virtual laboratory for science education that student success increases compared to classical laboratory method and moreover the laboratory applications after virtual laboratory experiments become more effective in learning the subjects. Bozkurt has also noted that simulations have removed the negative effects arising from physical facility deficiencies, eased the presentation of the experiments almost impossible to realize in laboratory environment and make possible to perform time consuming experiments effortlessly, hence using simulations in the classes of practical application is become more effective [5].

Daşdemir has researched effect of animation use in science and technology classes, and reported that the method is more effective compared to classical educational techniques. It is also reported that animation techniques is helping students make research on the subjects, get easier grasp of the subject, increase the motivation, concretize the abstract concepts, increase the permanency, empower and quicken the thinking abilities. Moreover, Daşdemir has suggested making comparison of the technique with other active learning methods in the future [9].

\section{The Object And Importance Of The Research}

In this study is aimed as a class material which is supported by animations and simulations on the subject of serial and parallel resistor circuits. Material creation objectives include quick and easy understanding of subject by the students, minimization of concept understanding mistakes, use as educational tool in the environments lacking laboratories and equipment's. So, computers animate the events hard to grasp subjects, dangerous and costly experiments or occurrences taking too much time to be properly observed [13].

\section{Preparation And Applications Of Materials}

First of all, simulations and animations about serial and parallel connected resistor circuits are prepared and how a voltmeter and an ammeter connected to a serial circuit along with values of current and voltage for each resistor at the experiment circuit thoroughly explained. Moreover, derivation of the serial connected resistor formulas for current, voltage resistance is also shown on the animation [13].

Later, parallel connected resistor circuit simulations are prepared. How an ammeter connected to the circuit is explained, first for the main branch current and later currents and voltages for each resistor are calculated. Mathematical operations are shown as animations and derivations of formula related to the subject are presented as animation for clear understanding of the concepts.

In this study, when the animations and simulations are prepared, relation of the animations and simulations to the subject, attraction of attention about subject and visuals are considered in priority. Attractiveness of the animations and simulations make students enjoy the application. While the simulations and animations are presented, the verbal knowledge which is given to the students and animations and simulations, are planned to be coherent each other. The knowledge to be gained by the students is also carefully planned to be in the class study for effectiveness of the animation and simulation. Thus, the mind of the student is not filled up by the unrelated garbage but students are planned to make connection between the previous class subjects. Comprehensibility of the figures and textures, consistency of used colours created movements in the computer are also given careful attention. The other factors like used colours not to be eye straining and clearness of the pictures are also carefully considered. Sound are also carefully added to the animations thus giving the vividness to the leaning process while presenting the educational elements and helping the students get the necessary clues about the subjects. Unexaggerated and natural sounds are preferred. Figures are chosen according to the ages of the students. Font style, type, colour and points are chosen according to their readability and animation movement perception compatibility. Every animation and simulation has forward and backward buttons to pass the desired part and calculate button is used to calculate numerical results. Long texts are avoided, thus presented knowledge to be more attractive and readable. The principle of "less information for the core of the subject" is chosen as the motto of the method [13].

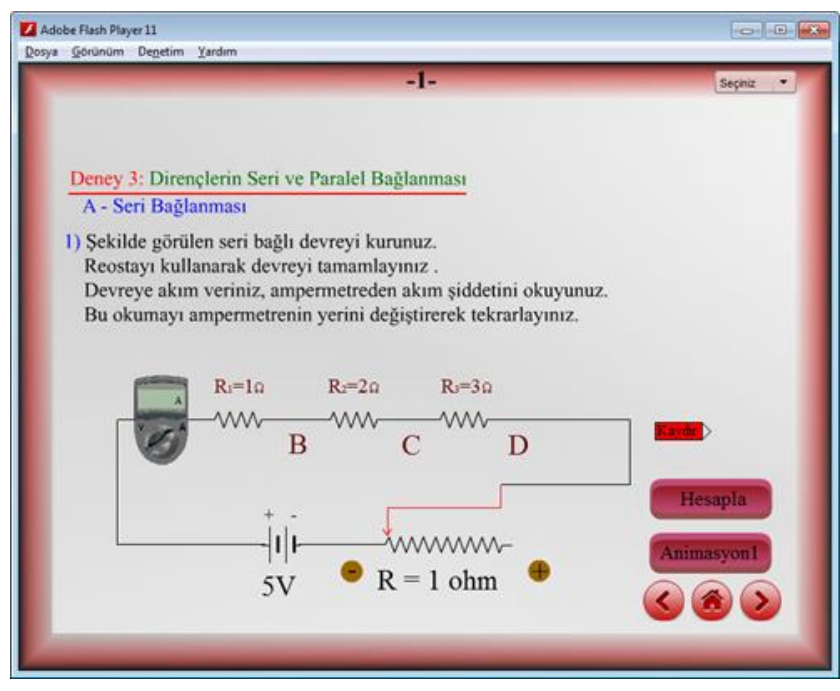

Figure 1. Serial connection simulation

Figure 1 shows how to connect an ammeter and measure main current and current passing through each resistor in a serial connected circuit. It also shows how to calculate main current and the current passing through each resistor by changing resistors with rheostat.

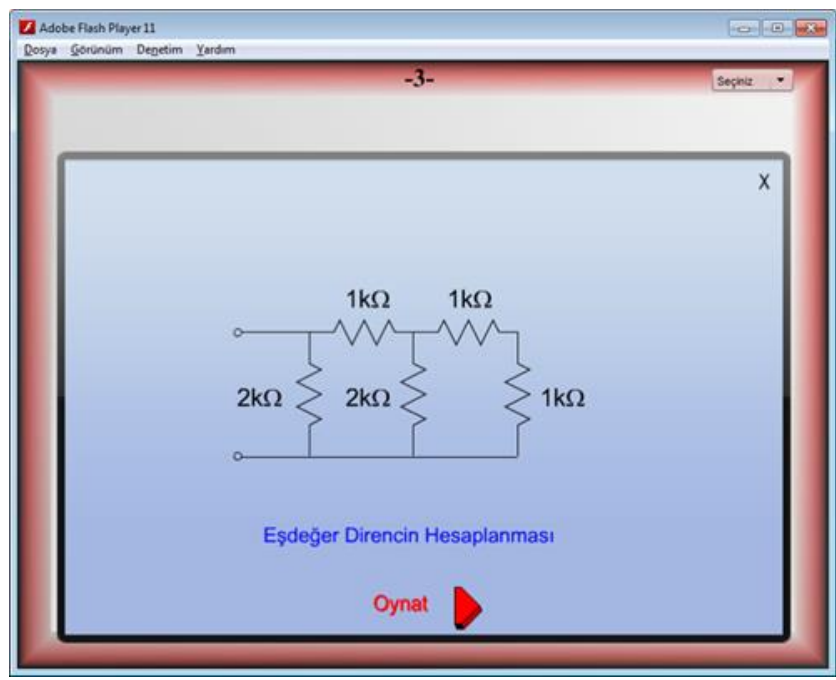

Figure 2. Equivalent resistance calculation animation 
Figure 2 shows how to calculate equivalent resistance in animation. So that students understand the subject better.

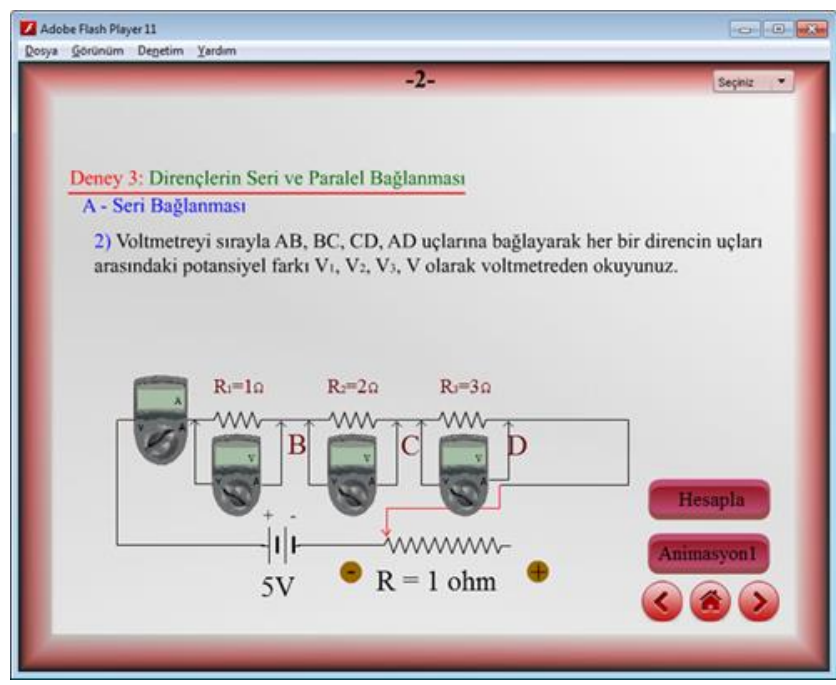

Figure 3. Animaton of voltmeter connection to the serial resistor circuit

Figure 3 shows how to connect a voltmeter in to a circuit and how to measure potential difference on each resistor with voltmeter. In addition, it also simulates measurements of the main branch current and voltages of each resistor when the resistance is changed by the rheostat.

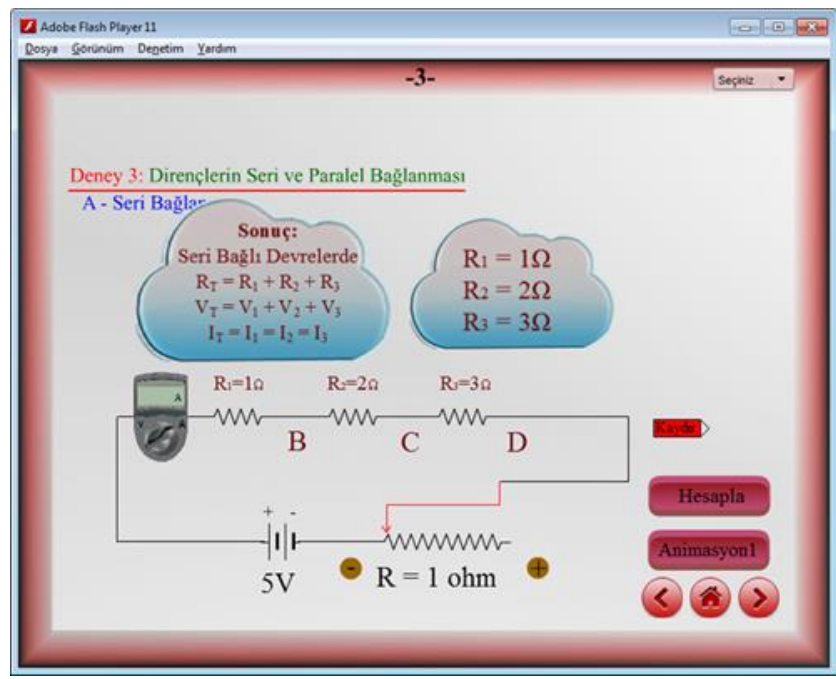

Figure 4. Serial connection resistance calculation formulas

Figure 4 shows derivation of main current formula, equivalent resistance and potential difference formulas in serial connected circuit and calculation of these values are shown in animation. Figure 5 shows how to connect resistors in parallel and ammeter in a parallel circuit. Also by making students observe connecting resistors and ammeter in computer couple of times, increases the permanency of knowledge in the memory of the students.

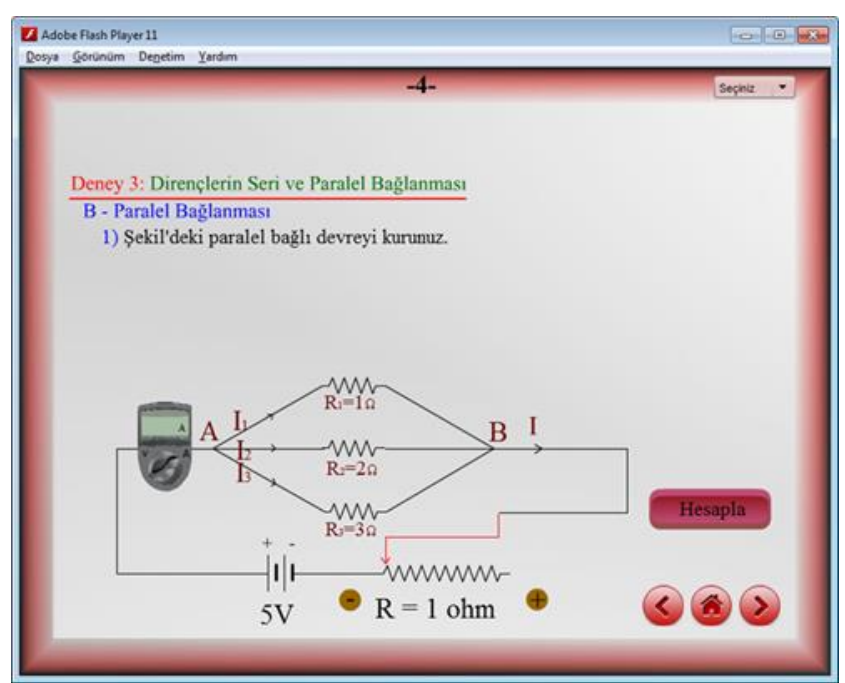

Figure 5. Animation of parallel connected resistor circuit

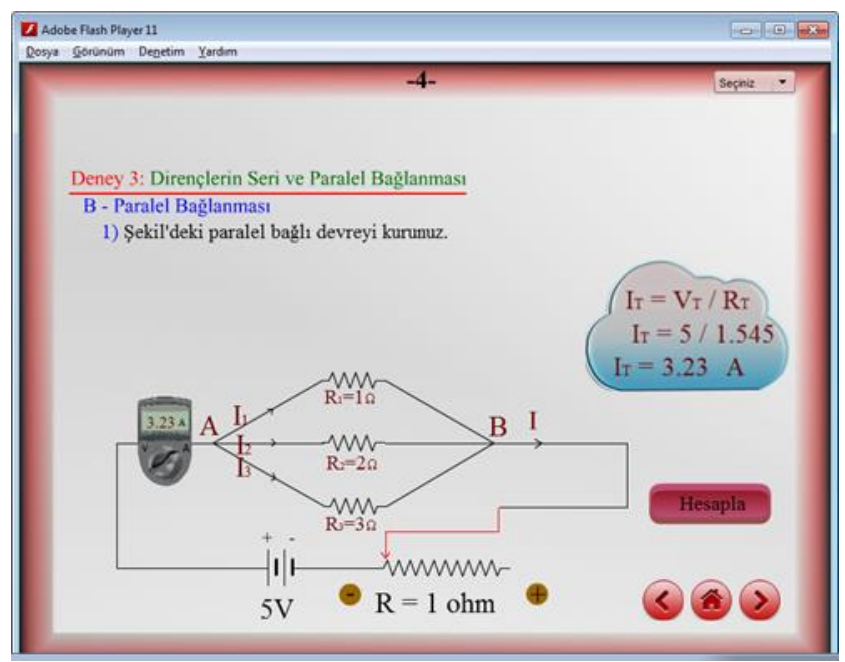

Figure 6. Parallel resistor circuit

Figure 6 shows how to connect resistors in parallel and measure the main branch current with ammeter. For better understanding, mathematical calculations are shown as animations.

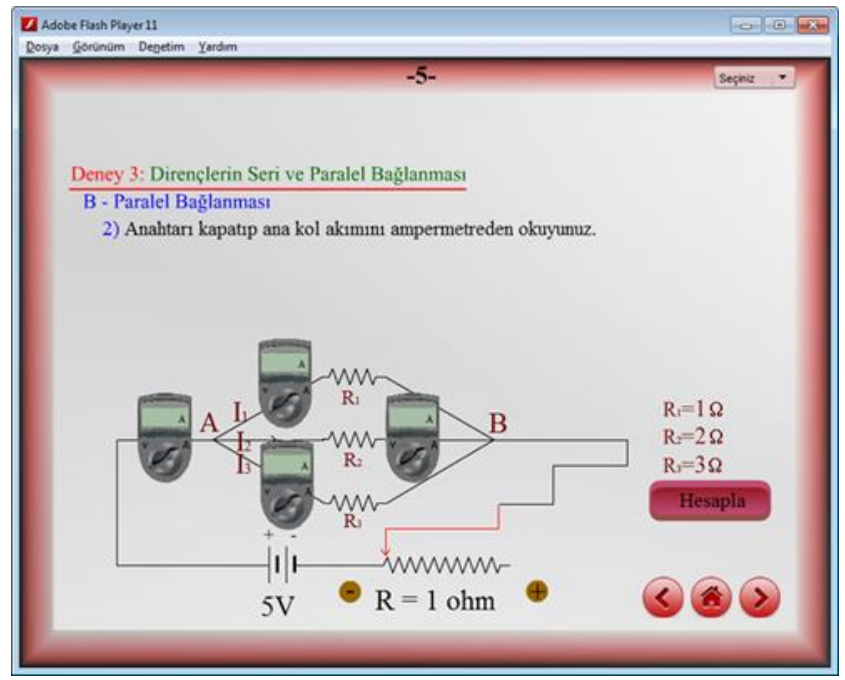

Figure 7. Calculations of parallel resistor circuit resistances.

Figure 7 shows how to connect an ammeter in a circuit. In order to making students understand better, colors, sounds and movement usage are taken into account carefully in the simulation. With the increased visual quality, better 
understanding is aimed.

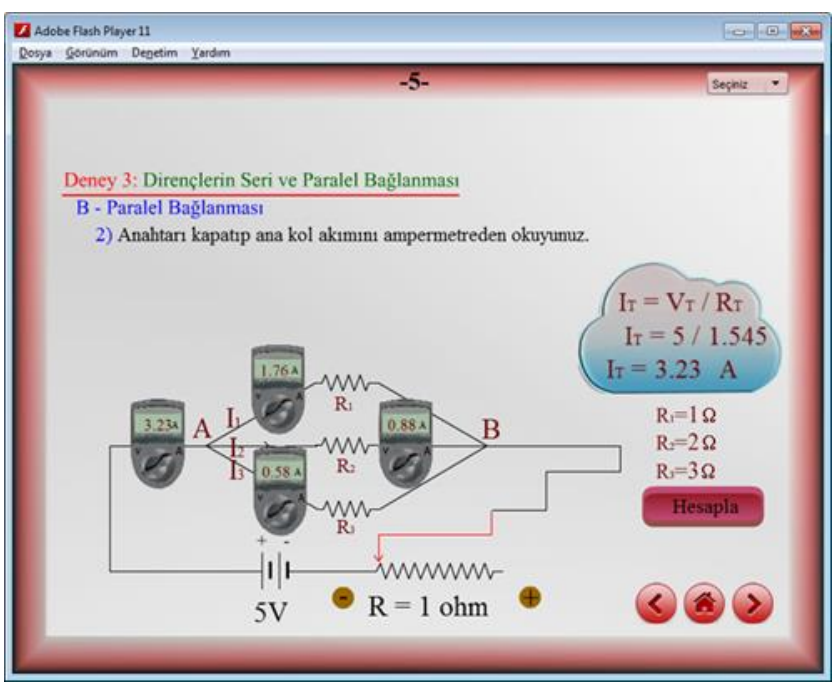

Figure 8. Presentation of currents and voltages over the resistors in parallel connected circuit

In Figure 8, how to read the current passing through the main branch by means of an ammeter is shown. By changing the rheostat resistance, recalculation of the currents are provided. By showing calculated results in a multi-meter, a similar scene is created as in the real laboratory environment

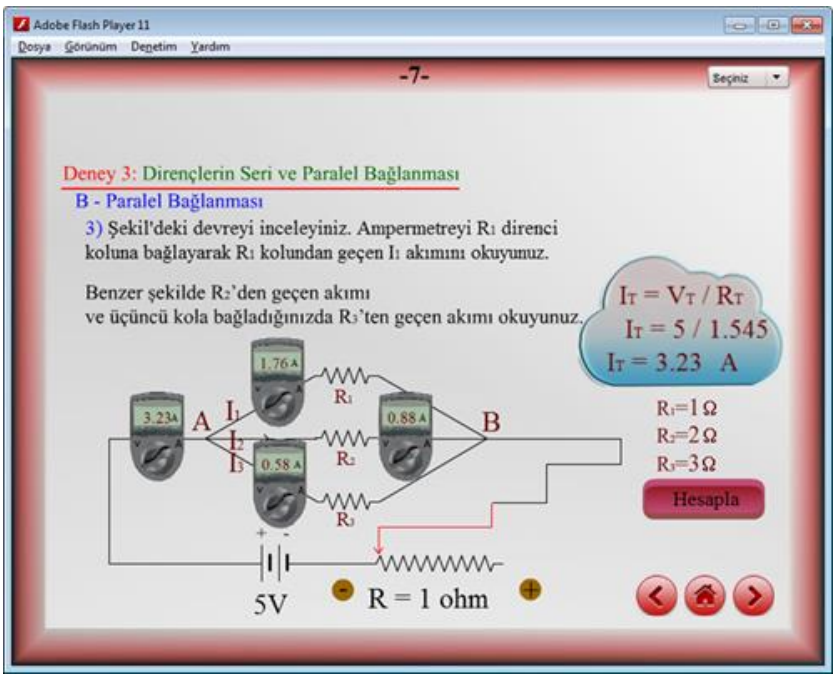

Figure 9. Connection of multi-meters in parallel resistor circuit. In Figure 9 students are asked to examine the given circuit and to read the current values of the multi-meters. Every animation and simulation has forward and backward buttons to pass the desired part of the experiment and calculate button is used to calculate numerical results.

In Figure 10, by reading the currents in the ammeters, verification of the equivalent current formula in parallel resistor circuits is observed. Later extracted values are placed in the Ohm's Law formula and currents are recalculated and read values of the experiments are verified. So that students understand the subject better.

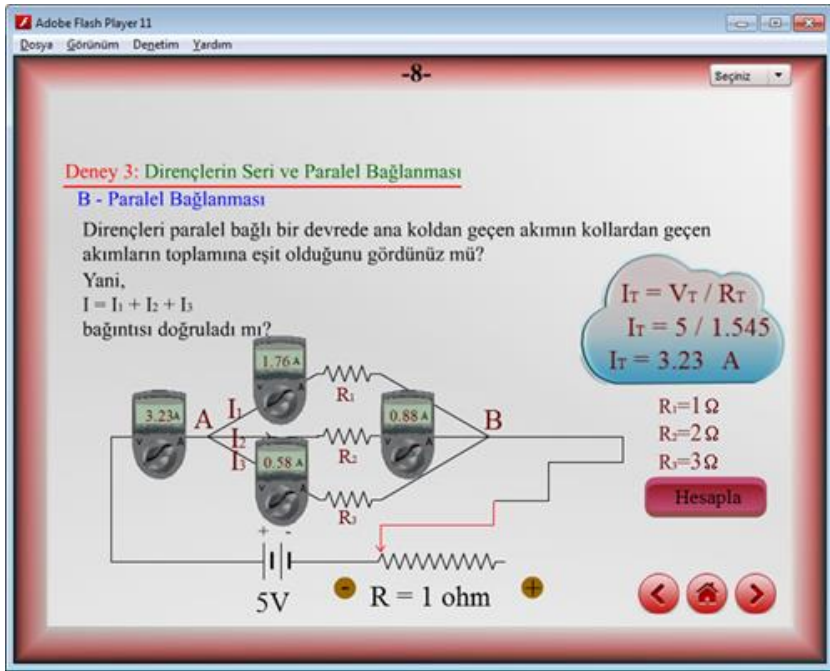

Figure 10. Current calculation formulas in parallel resistor circuit.

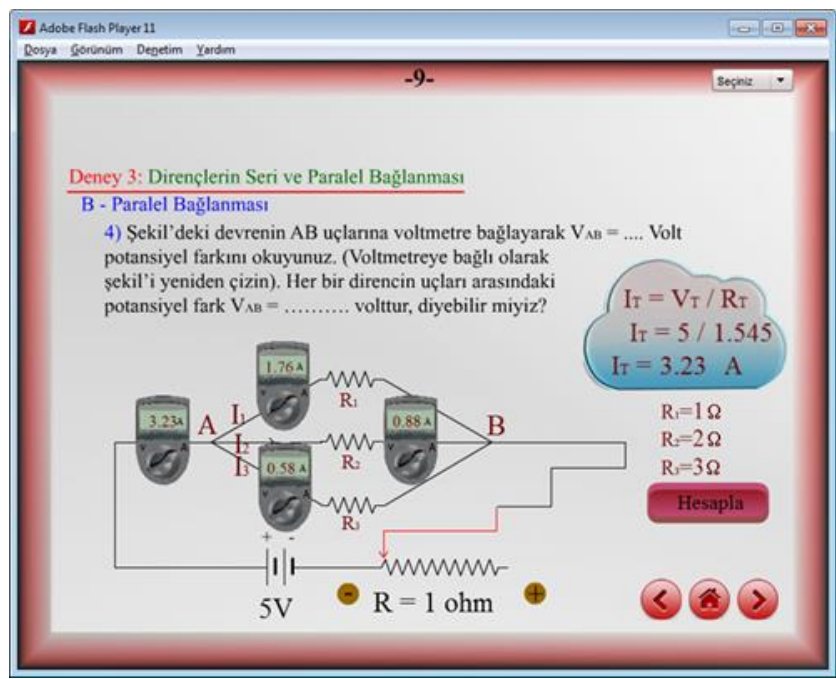

Figure 11. Current calculations and reading in the parallel circuit.

In Figure 11, main branch current is both read from the ammeter and calculated by using the numerical values in the animation and simulation. Later, students are asked to find voltage difference between the points A and B. So, students solidify the knowledge about the subject.

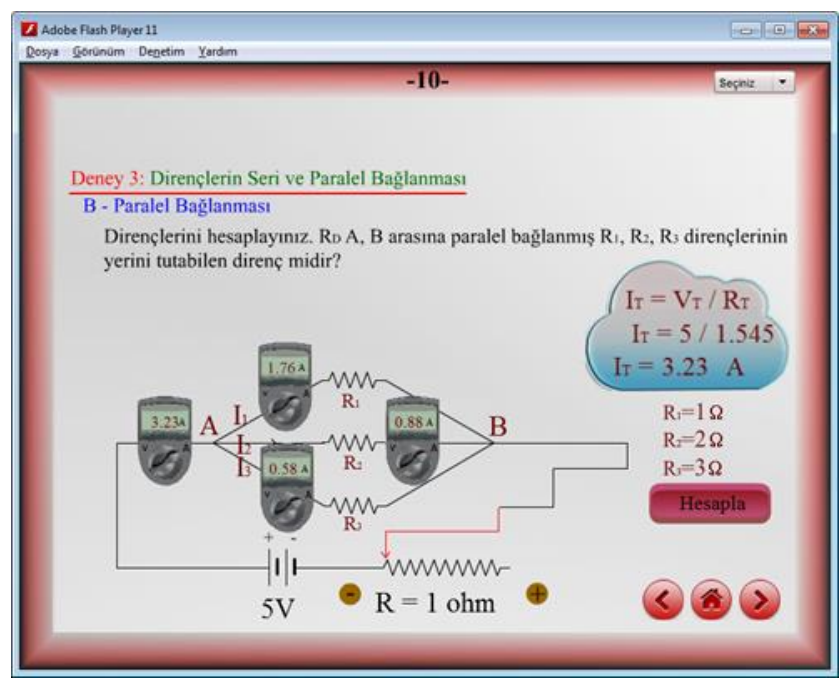

Figure 12. Calculation of values and presentation of the formulas. 


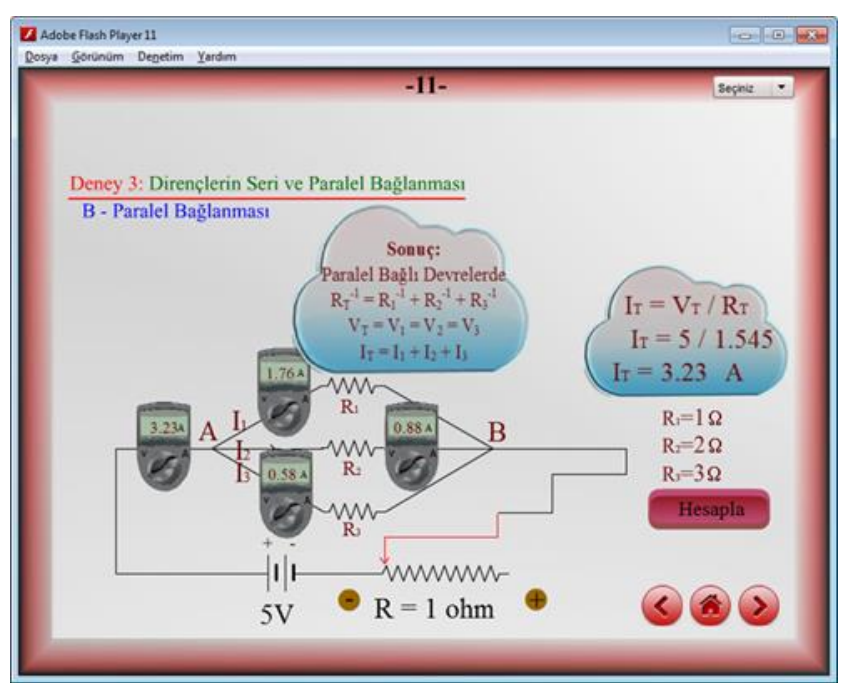

Figure 13. Show of the calculated results as an animation.

In the animations and simulations of the Figure 12 and Figure 13, formulas required to calculate equivalent resistance, equivalent current and equivalent voltage are given. When the calculate button is clicked, calculate numerical results are calculated [13].

\section{Conclusion}

It is thought that animation and simulation supported class explanations are effective for easy grasp of subjects by the students.

It is observed from the students participate to the experimental work reports that simulation of serial and parallel resistor circuits ease the understanding of the subject and minimizes the concept mistakes.

To increase the success to desired levels in physics and science classes should be progressed along with laboratory experiments. Some experiment cannot be performed because of laboratory insufficiencies or they may be hard to realize and dangerous experiments. In such cases use of simulations can be used by the students to increase the success and minimize the concept mistakes.

Computer laboratories are needed for proper simulation and animation of the class materials to use in curricula. Schools decided to use the method should get a proper computer laboratory if they already do not have any.

Hard to realize and dangerous experiments can be realized in computer environment with simulations and animations to transfer the subjects to the students.

The effect of class materials prepared by using animations and simulations on students' long term memory about the subjects can be studied in the future.

\section{References}

[1] Saka, A. Z., Fen öğretiminde kullanılan somutlaştırma araçları ve uygulama düzeyleri, IV. Ulusal Fen Bilimleri ve Matematik Eğitimi Kongresi, İstanbul, (2004), Cilt I, 245.

[2] Duru, N., Fizik Dersinde Analoji Kullanmanın Öğrenmeye ve Öğrenci Başarısına Etkilerinin Araştırılması. Yüksek Lisans Tezi, Marmara Üniversitesi Eğitim Bilimleri Enstitüsü, İstanbul, 2002.

[3] Türkoğuz, S. Fen bilgisi eğitiminde pratik ve teknolojik öğretim materyallerinin kullanımı. Yayımlanmamış yükseklisans tezi. Celal Bayar Üniversitesi, Manisa, 2002.

[4] Demirer, A. İlköğretim ikinci kademede bilgisayar destekli fen bilgisi öğretiminin öğrenci başarısına etkilerine ilişkin bir araştırma. Yayımlanmamış yüksek lisans tezi. Dicle Üniversitesi, Diyarbakır, 2006.

[5] Bozkurt, E. Fizik eğitiminde hazırlanan bir sanal laboratuvar uygulamasının öğrenci başarısına etkisi. Doktora tezi. Selçuk Üniversitesi, Konya, 2008.

[6] Başaran, B. Bilgisayar destekli öğretimin fizik eğitiminde öğrenci başarısı ve tutumuna etkisi. Yayımlanmamış yüksek lisans tezi. Dicle Üniversitesi, Diyarbakır, 2005.

[7] Lin, H., Dwyer, F., Swain, J. The effect of varied cognitive strategies used to complement animated instruction in facilitating achievement of higher order learning objectives. International Journal of Teaching and Learning in Higher Education. 18 (3), 2006, pp.155-167.

[8] Özcan, F. Dokuzuncu sinıf coğrafya öğretiminde animasyonların yeri ve önemi. Yayımlanmamış yüksek lisans tezi. Selçuk Üniversitesi, Konya, 2008.

[9] Daşdemir, İ. Animasyon kullanımının ilköğretim fen bilgisi dersinde akademik başarıya ve kalıcılığa etkisi. Yayımlanmamış yüksek lisans tezi. Atatürk Üniversitesi, Erzurum, 2006.

[10] Arıcı, N., Dalkılıç, E. Animasyonların bilgisayar destekli öğretime katkısı: bir uygulama örneği. Kastamonu Eğitim Dergisi. 14, 2006, pp.421-430.

[11] Çepni, S., Ayas, A., Johnson, D., Turgut, M. F. Bilimsel Süreç Becerileri. Fizik Öğretimi-Hizmet Öncesi Öğretmen Eğitimi. YOK/Dünya Bankası Milli Eğitimi Geliştirme Projesi, 1997, Ankara.

[12] Özmen, H. Fen Öğretiminde Öğrenme Teorileri ve Teknoloji Destekli Yapılandırmacı (Constructivist) Öğrenme. The Turkish Online Journal of Educational Technology - TOJET, 3, (14), 2004.

[13] Köklü, N., Genel Fizik Laboratuvarında Başarı ve Akılda Kalıcılık Etkilerinin Artırılmasına Yönelik Animasyon, Simülasyon ve Analojik Modellerin Geliştirilmesi, Doktora Tezi, Selçuk Üniversitesi Fen Bilimleri Enstitüsü, Konya, 2015. 